\title{
Integrating Air Quality and Public Health Benefits in U.S. Decarbonization Strategies
}

\author{
Ciaran L. Gallagher ${ }^{1 *}$ and Tracey Holloway ${ }^{1,2}$ \\ ${ }^{1}$ Nelson Institute Center for Sustainability and the Global Environment, University of Wisconsin-Madison, Madison, WI, \\ United States, ${ }^{2}$ Department of Atmospheric and Oceanic Sciences, University of Wisconsin-Madison, Madison, WI, \\ United States
}

\section{OPEN ACCESS}

Edited by:

Patrick Lott Kinney,

Boston University, United States

Reviewed by:

James Douglas Blando,

Old Dominion University, United States

Susan Anenberg,

George Washington University,

United States

*Correspondence:

Ciaran L. Gallagher

clgallagher@wisc.edu

Specialty section:

This article was submitted to

Environmental Health

a section of the journal

Frontiers in Public Health

Received: 18 May 2020

Accepted: 12 August 2020

Published: 19 November 2020

Citation:

Gallagher CL and Holloway T (2020)

Integrating Air Quality and Public

Health Benefits in U.S.

Decarbonization Strategies.

Front. Public Health 8:563358.

doi: 10.3389/fpubh.2020.563358
Research on air quality and human health "co-benefits" from climate mitigation strategies represents a growing area of policy-relevant scholarship. Compared to other aspects of climate and energy policy evaluation, however, there are still relatively few of these co-benefits analyses. This sparsity reflects a historical disconnect between research quantifying energy and climate, and research dealing with air quality and health. The air quality co-benefits of climate, clean energy, and transportation electrification policies are typically assessed with models spanning social, physical, chemical, and biological systems. This review article summarizes studies to date and presents methods used for these interdisciplinary analyses. Studies in the peer-reviewed literature $(n=26)$ have evaluated carbon pricing, renewable portfolio standards, energy efficiency, renewable energy deployment, and clean transportation. A number of major findings have emerged from these studies: [1] decarbonization strategies can reduce air pollution disproportionally on the most polluted days; [2] renewable energy deployment and climate policies offer the highest health and economic benefits in regions with greater reliance on coal generation; [3] monetized air quality health co-benefits can offset costs of climate policy implementation; [4] monetized co-benefits typically exceed the levelized cost of electricity (LCOE) of renewable energies; [5] Electric vehicle (EV) adoption generally improves air quality on peak pollution days, but can result in ozone dis-benefits in urban centers due to the titration of ozone with nitrogen oxides. Drawing from these published studies, we review the state of knowledge on climate co-benefits to air quality and health, identifying opportunities for policy action and further research.

Keywords: interdisciplinary, integrated assessment modeling, climate mitigation, electric vehicles (EV), renewable energy

\section{INTRODUCTION}

Fossil fuel combustion releases a complex mixture of emissions into the atmosphere, including carbon dioxide $\left(\mathrm{CO}_{2}\right)$, carbon monoxide $(\mathrm{CO})$, and nitrogen oxides $\left(\mathrm{NOx}=\mathrm{NO}_{2}+\mathrm{NO}\right)$, as well as primary particulate matter $(\mathrm{PM})$, sulfur dioxide $\left(\mathrm{SO}_{2}\right)$ and other compounds depending on the fuel and combustion process. Carbon dioxide emissions are primarily a concern due to their radiative impacts on the planet and role in climate change, while the other emissions impact human health through degraded air quality (1). In fact, exposure to health-damaging air pollution is the largest environmental impact on human health, responsible for 4.2 million lives lost each year (2). 
Greenhouse gases (GHGs), especially $\mathrm{CO}_{2}$, are co-emitted with health-damaging air pollutants in power plants, vehicles, and other sources of fuel combustion. While GHGs themselves can have direct and indirect health impacts (3), they differ from "traditional air pollutants" with well-established effects on human health through respiratory exposure. Epidemiological and toxicological studies clearly identify adverse health outcomes associated with $\mathrm{PM}$ and certain reactive gases, including ozone $\left(\mathrm{O}_{3}\right), \mathrm{CO}, \mathrm{NO}_{2}$, and $\mathrm{SO}_{2}$. Based on these health studies, these health-relevant pollutants have been regulated in the United States since 1970. The World Health Organization (WHO) also provides exposure guidelines for these traditional air pollutants (4). To clarify this distinction, we use the term "air quality" to refer to the abundance of chemicals in the air with well-established impacts on health, and "climate pollutants" to refer to chemicals in the air that affect the radiative balance of the planet by absorbing, reflecting, and/or re-emitting radiation. This distinction is important to emphasize "co-benefits" where actions to decrease climate pollution also benefit air quality and human health.

The potential for energy system changes to offer co-benefits for both climate and public health is shown in Figure 1, where reductions in fossil fuel burning reduce a range of pollutants. The term "criteria" air pollutants refers to the six air pollutants regulated in the United States under the National Ambient Air Quality Standards: $\mathrm{SO}_{2}, \mathrm{NO}_{2}, \mathrm{CO}, \mathrm{PM}, \mathrm{O}_{3}$, and lead $(\mathrm{Pb})(5)$. This group of pollutants overlaps with air pollution guidance from the WHO and threshold-based regulation in the European Union (6) and China (7). While all criteria air pollutants have well-established health impacts, $\mathrm{PM}$ and $\mathrm{O}_{3}$ have had a greater focus in the energy co-benefits literature due to their more frequent non-attainment status (8).

Both $\mathrm{PM}$ and $\mathrm{O}_{3}$ are considered regional air pollutants, mixing over synoptic scales due to chemical processes that promote their formation. Both $\mathrm{PM}$ and $\mathrm{O}_{3}$ are also sensitive to weather conditions, which affect mixing in space and chemical processes. These weather dependencies suggest that $\mathrm{O}_{3}$, and to a lesser degree PM, will be worsened by climate change, as discussed in the Appendix [e.g., $(9,10)]$. The regional nature of these pollutants complicates the attribution of co-benefits. Local actions, such as retiring a coal-fired power plant, typically yield health and air quality co-benefits to the location where the emission reduction occurred (e.g., the county containing the retired power plant) as well as an area downwind. The location and magnitude of these benefits depend on weather patterns, atmospheric chemistry, and the distribution of the exposed population.

Evaluation of air quality and public health co-benefits of carbon strategies dates to the 1990s (11-13). Some of the earliest investigations of air quality co-benefits, then called "ancillary benefits," were conducted by or for the U.S. Environment Protection Agency $(14,15)$. The earliest published studies utilized economic models that incorporated simplified air pollution scaling factors (16-18). These first studies demonstrated that there can be significant air quality co-benefits for climate and energy policies. For example, Tollefsen et al. (18) concluded that incorporating the climate impacts of air pollutants into European
Union air quality strategies can avoid $7.3 \%$ of damages to human health and crops through efficiency gains. Bollen et al. (17) found that climate policies result in lower local air pollution and that the benefits largely outweigh the $\mathrm{CO}_{2}$ and $\mathrm{PM}_{10}$ emissions reduction costs.

Early studies were influenced by environmental concerns of acidification and eutrophication, which were reflected in international policies of the time including the 1979 Convention on Long-Range Transboundary Air Pollution (LRTAP) (19). One of the first reduced-form models used to evaluate co-benefits was the RAINS model (20), which optimized emission scenarios to co-manage acidification, eutrophication, and ground-level $\mathrm{O}_{3}$ impacts $(17,21,22)$. In addition to RAINS, the Tracking and Analysis Framework (23), and stack-height-differentiated dispersion models (24) represented pioneering efforts to evaluate health and air quality impacts of energy system change. As efforts advanced to quantify benefits over multiple pollutants and multiple areas of impact, especially climate, this research domain began to be referred to as "co-benefits."

With the evolution of computer processing, more advanced models could be developed and applied to air quality assessment. These "full physics" atmospheric models directly solve the mathematical equations representing fluid advection and atmospheric chemistry, from the regional to global scale. From the models, near-surface air quality was calculated as a function of changing emissions (25-27). These early studies supported the integrated, interdisciplinary analyses of air quality co-benefits that are the focus of this review.

In the 2000s, editorial essays and review articles identified the need for increased linkages among disciplines to quantify air pollution co-benefits (28-31). These papers argued that air quality analyses should be considered in climate change adaptation, planning, and policy decisions due to the public health potential of decarbonization measures. In particular, Bell et al. (28) reported a broad consensus across the literature that decarbonization can substantially improve air quality, despite the fact that publications to date had mostly conducted a single step of analysis (e.g., economic, emissions, air quality, or health), rather than providing an integrated assessment. A meta-analysis by Nemet et al. (32) found air quality co-benefits $\left(\$ / \mathrm{tCO}_{2}\right)$ in the range of $\$ 2-196 / \mathrm{tCO}_{2}$. Studies included in that review included stack-height-differentiated dispersion models, simplified sourcereceptor relationship models, and scaling factors. Nemet et al. (32) did not include studies investigating the spatial and temporal air quality effects of clean transportation options, like electric vehicles (EVs), which were only beginning to emerge as a topic of analysis at the time. Analysis methods have advanced considerably since these earlier reviews, and we focus on the common findings and tradeoffs of newer analysis approaches.

Air quality models and integrated analysis methodologies enable more comprehensive as well as more spatially and temporally complex evaluation of air quality co-benefits. We focus on these model-based analyses of climate mitigation policies and technologies, as well as specific transportation and electricity sector decarbonization strategies. Across published studies, a number of consistent findings have emerged, as well as opportunities for policy action and further research. Section 


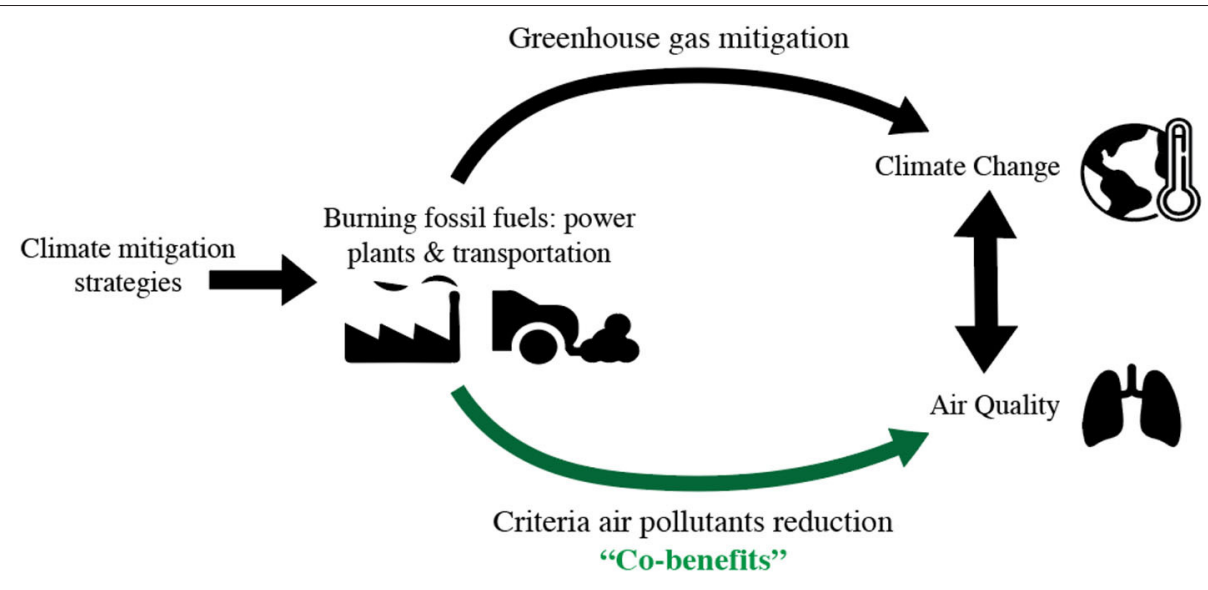

FIGURE 1 | A schematic of the co-benefits from climate mitigation strategies due to the relationships between climate change and air quality.

Study selection defines the criteria for study selection; Section Summary of published studies outlines the studies included in this review; Section Models and Methods presents the models and methods used across these co-benefit studies; Section Results presents results of our review; and section Conclusion presents conclusions and research needs. It should be noted that even the most advanced models do not determine policy outcomes. Energy planning takes place in a complex political and economic environment, both in the U.S. and in countries around the world. Even as models advance different actors will perceive results, including the distribution of benefits and costs, based on personal and institutional perspectives. Here we focus on the analysis tools available to support quantifying air quality and health co-benefits, recognizing that policy outcomes occur beyond the calculations of even the most sophisticated models.

\section{STUDY SELECTION}

To conduct this review, we focus on peer-reviewed analysis included in the Clarivate Analytics Web of Science platform (WoS), as of in February 2020. The scope is limited to interdisciplinary analysis of changes in emissions and air quality from climate mitigation scenarios. We define climate mitigation to be a purposeful action taken to decrease $\mathrm{CO}_{2}$ emissions in order to slow global warming. These scenarios can include energy sector regulations, carbon taxes, or an increase in renewable energy or EVs. For inclusion in this review, we require that air quality analysis include the calculation of ambient concentrations from pollutant emissions; research studies that only used scaling factors to approximate public health benefits from emissions were not included.

Research on the health impacts of climate and air quality represents a small fraction of the work evaluating health impacts of climate alone or of air quality alone. Where a WoS search with keywords "climate" + "health" yields 28,580 results and "air pollution" + "health" yields 24,893 studies, a WoS search with the keywords "climate co-benefits" yields only 1,069 research studies and the keywords "air pollution" + "climate change" returns 3,540 results. The subset of co-benefits research appears to be $4-14 \%$ of the research on the health impacts of climate or air pollution alone. To systematically narrow the field of research to the interdisciplinary modeling studies at the heart of this review, we began with WoS keywords: "climate change air pollution co-benefit," (200+ results) and "transportation air pollution co-benefit," (50+ results).

Abstracts of these papers were reviewed to assess if the study: [1] quantified air quality co-benefits from climate mitigation actions and [2] analyzed both emissions and air quality. Papers were excluded that did not match these criteria. There are a number of closely related fields of study that we exclude from this review scope, including research that: [1] evaluates the climate forcing potential of fuel switching $(33,34)$; [2] omits an explicit calculation of emissions associated with the policy or technology $(35,36)$; [3] calculates $(25,37)$ or applies $(11,12,17,38,39)$ scaling factors to approximate air quality impacts; [4] uses optimization methods to evaluate the most cost-effective way to achieve air quality and greenhouse gas reduction targets (11, 17, 40-43); [5] assumes a fixed criteria air pollutant or greenhouse gas emissions reduction (44-48), including zeroing out the emissions of a particular sector (49) and global warming temperature targets (50-55); [6] evaluates climate change's impact on air pollution without the context of a climate mitigation action $(56,57)$; [7] conducts life cycle assessments (58); and [8] has not been published in peerreviewed journals $(15,59)$. Beyond the papers from the WoS keyword searches, we included research cited by retrieved papers or that cited retrieved papers, as long as papers met our inclusion criteria. We focus on United States policies and analysis; studies of other regions are included in Table S1 and discussed in Appendix II (27, 60-70).

Twenty-six studies met our inclusion criteria, which are listed in Tables 1-3. Seventeen of these quantify the human health and associated economic benefits of the air quality changes. The other nine report changes in ambient air pollution concentrations, but not health impacts. A related review on the air quality benefits of EVs was presented by Requia et al. (95), and included 65 studies, 
TABLE 1 | Scope and methods for research included in the literature review of climate policy air quality co-benefits.

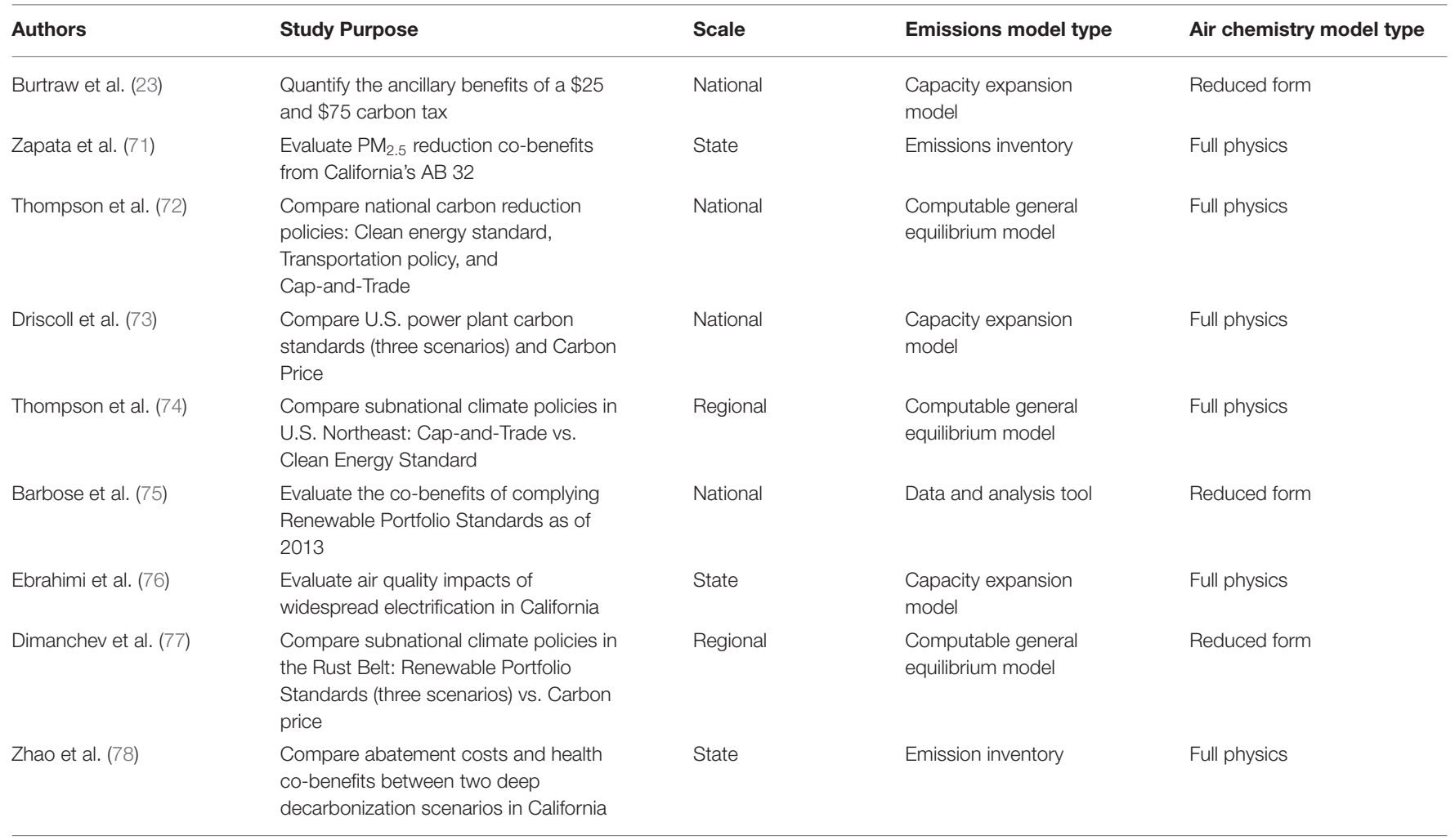

TABLE 2 | Scope and methods of electricity generation and renewable energy deployment co-benefits research.

\begin{tabular}{|c|c|c|c|c|}
\hline Authors & Study Purpose & Scale & Emissions model type & Air chemistry model type \\
\hline $\begin{array}{l}\text { McCubbin and } \\
\text { Sovacool (79) }\end{array}$ & $\begin{array}{l}\text { Evaluate the air quality benefits from } \\
\text { deploying wind power in California and Idaho }\end{array}$ & Regional & Emissions inventory & Reduced form \\
\hline Buonocore et al. (81) & $\begin{array}{l}\text { Compare four scenarios: } 500 \mathrm{MW} \text { wind, } 500 \\
\text { MW solar, } 500 \mathrm{MW} \text { reduced peak load, and } \\
150 \mathrm{MW} \text { reduced baseload in six locations } \\
\text { in the PJM Interconnection }\end{array}$ & Regional & Production cost model & Reduced form \\
\hline Wiser et al. (82) & $\begin{array}{l}\text { Evaluate benefits of solar PV deployment of } \\
14 \% \text { in } 2030 \text { and } 27 \% \text { in } 2050\end{array}$ & National & $\begin{array}{l}\text { Capacity expansion } \\
\text { model }\end{array}$ & Reduced form \\
\hline Millstein et al. (83) & $\begin{array}{l}\text { Quantify co-benefits from actual 2007-2015 } \\
\text { PV and wind deployment }\end{array}$ & National & Data and analysis tool & Reduced form \\
\hline Abel et al. (84) & $\begin{array}{l}17 \% \text { electricity generation replaced with PV } \\
\text { in Eastern U.S. }\end{array}$ & Regional & Production cost model & Full physics \\
\hline Buonocore et al. (86) & $\begin{array}{l}\text { Scenarios of deploying 100-3,000 MW } \\
\text { renewable energy (wind, utility solar PV, } \\
\text { rooftop solar PV) in different U.S. regions }\end{array}$ & National & Data and analysis tool & Reduced form \\
\hline
\end{tabular}

ten of which are also included here. That review includes research excluded from this review, such as life-cycle assessments and emissions-only analysis. By evaluating carbon, transportation, and electricity strategies, we focus here on consistent findings about fossil fuel reduction impacts on air quality and health. 
TABLE 3 | Scope and methods for transportation focused research.

\begin{tabular}{|c|c|c|c|c|}
\hline Authors & Study Purpose & Scale & Emissions model type & Air chemistry model type \\
\hline Thompson et al. (26) & $\begin{array}{l}\text { Replace } 20 \% \text { of conventional vehicles } \\
\text { with plug-in hybrid EVs during an } \\
\text { August } 2002 \text { air pollution episode in the } \\
\text { PJM area }\end{array}$ & Regional & Emissions inventory & Full physics \\
\hline Brinkman et al. (87) & $\begin{array}{l}\text { Ozone impacts of } 30 \text { vs. } 100 \% \text { plug-in } \\
\text { hybrid EVs in Denver with and without } \\
\text { controlled charging }\end{array}$ & Metropolitan & $\begin{array}{l}\text { Electricity dispatch } \\
\text { model, Emissions } \\
\text { inventory, Mobile } \\
\text { emissions simulator }\end{array}$ & Full physics \\
\hline Grabow et al. (88) & $\begin{array}{l}\text { Eliminate short automobile trips }(< \\
8 \mathrm{~km}) \text { in } 11 \text { metropolitan areas in the } \\
\text { Upper Midwest }\end{array}$ & Regional & Emissions inventory & Full physics \\
\hline Bickford et al. (89) & $\begin{array}{l}\text { Shift freight transport from truck to rail } \\
\text { in the Upper Midwest }\end{array}$ & Regional & $\begin{array}{l}\text { Emissions inventory, } \\
\text { Mobile emissions } \\
\text { database }\end{array}$ & Full physics \\
\hline Razeghi et al. (91) & $\begin{array}{l}\text { Comparisons of } 40 \% \text { PHEV vs. BEV } \\
\text { penetration baseline vs. increased wind } \\
\text { energy, and controlled charging or not } \\
\text { scenarios in California's South Coast Air } \\
\text { Basin }\end{array}$ & Regional & $\begin{array}{l}\text { Electricity dispatch } \\
\text { model, Emissions } \\
\text { inventory, Mobile } \\
\text { emissions database }\end{array}$ & Full physics \\
\hline $\begin{array}{l}\text { U.S. Environmental } \\
\text { Protection Agency (92) }\end{array}$ & $\begin{array}{l}\text { Co-benefits assessment of federal GHG } \\
\text { emissions and fuel efficiency standards } \\
\text { for medium- and heavy-duty vehicles }\end{array}$ & National & Emissions inventory & Full physics \\
\hline Nopmongcol et al. (93) & $\begin{array}{l}\text { Air quality impacts of electrifying } 17 \% \\
\text { light duty and } 8 \% \text { heavy duty VMT as } \\
\text { well as } 79 \% \text { off-road equipment }\end{array}$ & National & $\begin{array}{l}\text { Optimization tool, } \\
\text { Mobile emissions } \\
\text { simulator, Mobile } \\
\text { emissions database }\end{array}$ & Full physics \\
\hline
\end{tabular}

\section{SUMMARY OF PUBLISHED STUDIES}

The number of studies calculating air quality benefits of climate and energy in the United States has grown over the past 20 years, as shown in Figure 2, which includes all studies listed in Tables 1-3. In Table 2, green denotes climate policies, orange denotes transportation policies/technologies and blue denotes electric sector or renewable energy policies/technologies. The earliest research included here dates to 2003, with integrated air quality co-benefits research gaining momentum starting in the early 2010s. In the last 6 years, published research in the field has doubled or tripled, peaking at six studies in 2016 and five in 2019.

Studies focused on climate policies are listed in Table $\mathbf{1}$, which include carbon taxes, renewable portfolio standards, and other traditional policies leveraged by national and state governments to reduce carbon emissions. Analyses of multiple energy scenarios, including transportation and/or renewable energy strategies, have been categorized as a climate policy as they evaluate multiple strategies to decrease carbon emissions. All except Ebrahimi et al. (76) calculate health and associated economic benefits of climate policies. Most of these studies take an economic modeling approach to emissions calculations, with three using a computable general equilibrium model $(72,74,77)$; three, a capacity expansion model $(23,73,76)$; one, a data and analysis tool (75); and one, an emissions inventory (71). Most use a full-physics air quality model; only Dimanchev et al. (77) uses the reduced form model, InMAP.

Studies that evaluate changes to electricity generation, including reduced demand from energy efficiency as well as renewable energies, are listed in Table 2. All except Plachinski et al. (80) calculate the public health benefit and associated economic metrics of the changes to air quality. Four compare the co-benefits of different renewable energy deployments in various regions of the U.S. $(79,81,83,86)$; two, the air quality co-benefits of renewable energy deployed across the continental United States $(82,85)$. Emissions were quantified with data and analysis tools $(83,85,86)$, a capacity expansion model $(80,82)$, a production cost model $(81,84)$ or an emissions inventory $(79)$. Most use a reduced-form air quality model; only Abel et al. (84) and Plachinski et al. (80) use a full physics air quality model to evaluate energy efficiency and renewable energy benefits.

Table 3 lists transportation-focused research, which includes co-benefits analysis of mode shifting $(88,89,93)$ and EV adoption $(26,87,90,91,94)$. Three studies included the air 


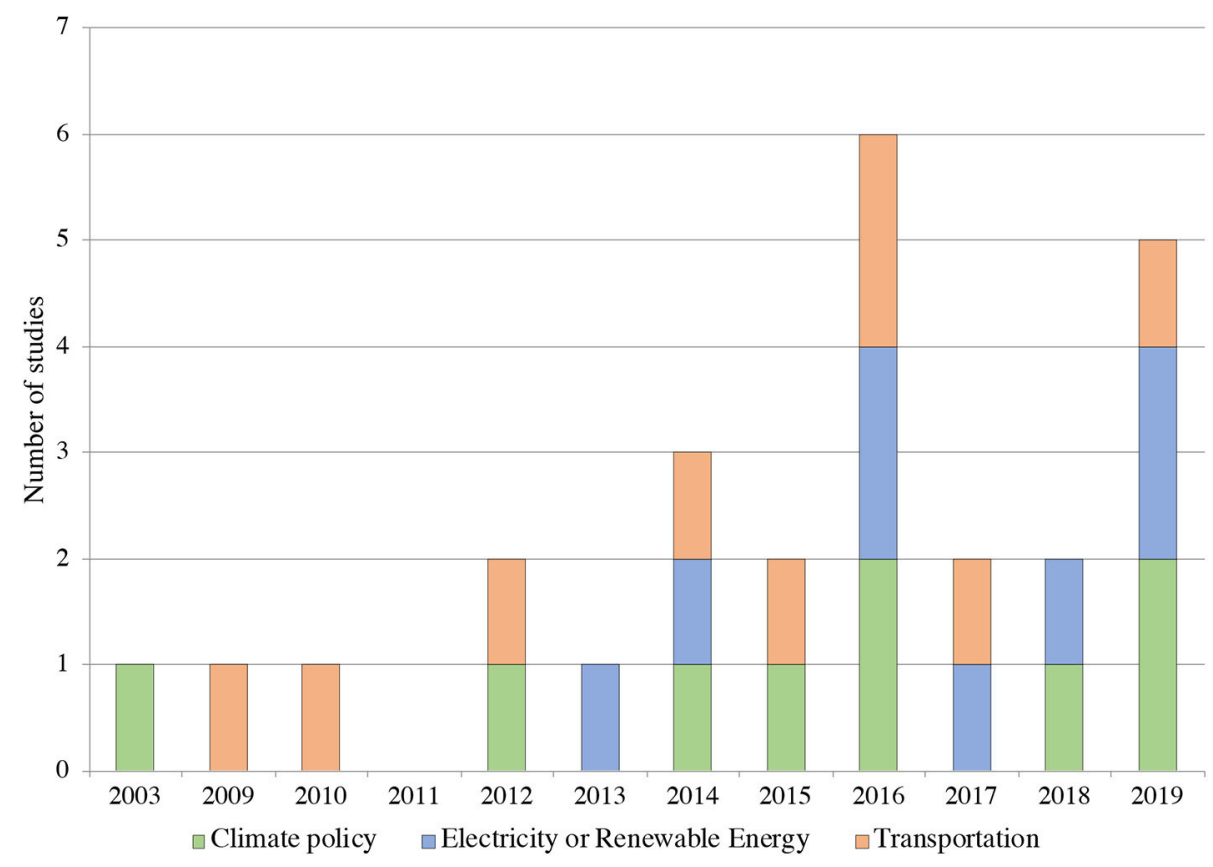

FIGURE 2 | Histogram of research included in literature review by publishing date. The table is color coded to specify the type of climate mitigation strategy or policy evaluated in the studies: green indicates climate policies, blue indicates electricity generation or renewable energy deployment or policy, and orange indicates transportation. A majority of the research included in this review was published in the last 5 years, with the oldest study dating 2003.

quality impacts of EV adoption with a cleaner future electricity grid $(87,90,91)$. Two studies investigated EV adoption in the Pennsylvania-New Jersey-Maryland (PJM) Interconnection: the regional transmission that serves parts of the Mid-Atlantic and Upper Midwest and is the most coal intensive grid in the United States $(26,90)$. Transportation-focused studies include two that focus on the air quality of metropolitan areas $(87,94)$ and one on a regional air basin (91). The smaller domains facilitate finer-scale analysis of spatial and temporal changes to $\mathrm{O}_{3}$ and other pollutants. As such, these studies primarily utilize full physics models [used in seven of the eight studies: $(26,87-89,91,93,94)]$. Quantification of health and economic benefits was rarer for the transportation studies; only two out of the eight included this analysis step $(88,94)$. Every study in Table 3 used an inventory approach to calculate vehicles tailpipe and/or EV charging electricity emissions. Mobile emissions inventories were supplemented with emissions factor databases $(89,91,93)$. Mobile emissions simulators, like the EPA's MOVES model $(89,93,94)$ and Argonne National Laboratory's GREET model (90), were also utilized to estimate mobile emissions. Emissions from charging EVs were estimated with a variety of methods including a unit commitment and dispatch model $(87,90)$, an electricity dispatch model $(91)$, and an optimization tool (93).

\section{MODELS AND METHODS}

As identified in our literature review (presented in Tables 1-3), research is expanding in the use of multi-model analysis to calculate air quality and health benefits of energy system change. Electricity dispatch models, economic models, and/or mobile emissions inventories are used to calculate time-sensitive and location-specific emission perturbations associated with a policy or technology change. The resulting emissions inventories are input into atmospheric chemistry models, or reduced-form models, to evaluate the impact of weather and chemistry on the distribution of ambient pollutants. Finally, the human health and economic impact from resulting ambient air quality concentrations are quantified using concentration response functions, population distribution data, and assumptions on the value of a statistical life. Table 4 introduces the models used in these studies.

Models used to quantify perturbations in emissions are shaded gray in Table 4. These include computable general equilibrium models (CGE) and power sector models, as well as transportation emissions models and evaluation tools developed by the U.S. EPA. Within power sector models there are multiple approaches $(96,97)$, two of which were used in the literature in this review: capacity expansion models and production cost models.

Here we discuss the emissions models in Table $\mathbf{4}$ as they relate to these general model categories:

- Economic CGE models simulate how different sectors of the economy impact energy and resource uses.

- U.S. Regional Energy Policy (USREP) model (98) was used in three studies $(72,74,77)$. 
TABLE 4 | Table of models used in literature included in review.

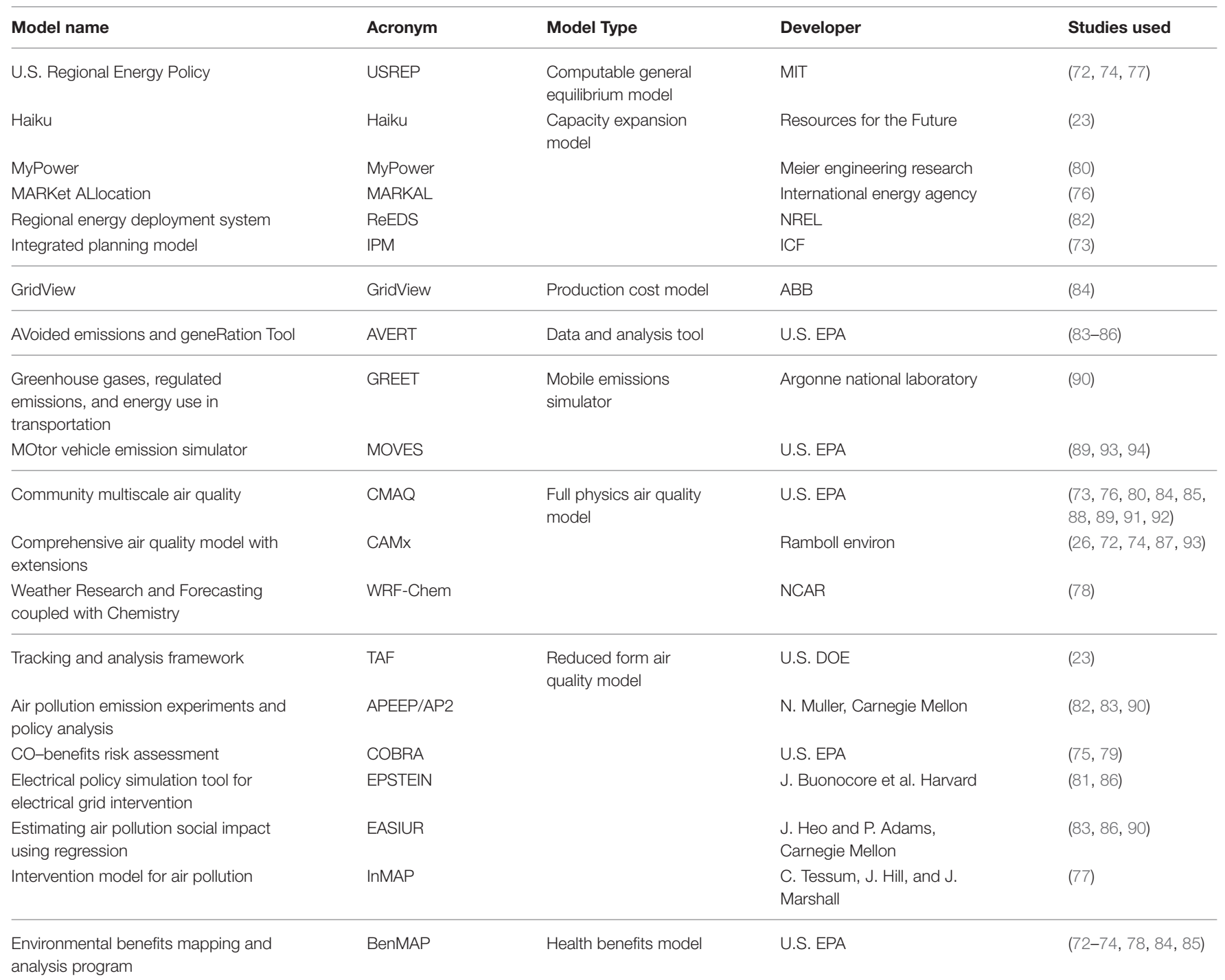

Table includes type, developer, and studies used.

- Capacity expansion models, a subset of power sector models, simulate generation and transmission capacity, and find the optimal mix of generators to meet demand.

- Haiku (99) was used in Burtraw et al. (23).

- MyPower (100) was used in Plachinski et al. (80); this model has since been renamed JuiceBox.

- International Energy Agency's MARKet ALlocation model (MARKAL) (101) was used in Ebrahimi et al. (76).

- NREL's ReEDS model (102) was used in Wiser et al. (82).

- ICF Resources L.L.C.'s Integrated Planning Model (IPM $\left.{ }^{\circledR}\right)$ (103) was used in Driscoll et al. (73).

- Power sector models, a subset of production cost models, simulate chronological unit commitment and dispatch at high temporal resolution (minutes to hours) with detailed representation of transmission linkages.
- ABB's GridView (104) was used in Abel et al. (84).

- A simplified data and analysis tool was developed by the U.S. EPA for wider adoption and easier implementation.

- U.S. EPA's AVoided Emissions and geneRation Tool (AVERT) (105) was the most used emissions model, used in four studies (83-86).

- Transportation emissions depend on fleet vehicle types, fuel efficiencies and travel patterns, typically measured as vehicle miles traveled (VMT), which are in turn dependent on public transportation services, housing density, and job center locations $(106,107)$.

- U.S. EPA's MOtor Vehicle Emission Simulator (MOVES) (108) was used in three studies $(87,93,94)$ to simulate end-of-pipe emissions. 
- Greenhouse Gases, Regulated Emissions, and Energy Use in Transportation (GREET) model (109) was used in Weis et al. (90) to capture the entire fuel-cycle, including electricity emissions relevant for EVs.

Beyond the six studies using MOVES or GREET, twelve studies use bottom-up emissions inventories $(89,91,93,110)$. Emissions inventories and electricity dispatch models were used to allocate power plant emissions resulting from the additional vehicle charging load $(87,90,91)$.

Air quality models are shaded in blue on Table 4. Two approaches have been used to extend emissions impacts to air quality and health: full physics models and reduced-form models. We use the term "full physics" to reflect the category of three-dimensional, chemical transport models (also called Eulerian models) which quantify changes in air quality due to weather, chemical processes, and deposition as well as emissions from natural and anthropogenic sources. In contrast, reduced form (or receptor-based) models are based on atmospheric model simulations and use simplified relationships (like source-receptor matrices) to estimate air quality and/or health associated with perturbed emissions. A third category of air quality model (Lagrangian dispersion models) is useful for source attribution and plume-modeling that is common for assessing the impact of individual point sources like power plants. These studies are outside of the scope of this review.

Three full physics atmospheric models were used across nineteen studies to evaluate spatial and temporal changes in ambient air pollution:

- U.S. EPA's Community Multiscale Air Quality model [CMAQ; (111)] was the most frequently used full physics model in these studies $(73,76,80,84,85,88,89,91)$. CMAQ is an open-source, state-of-the-art model that may be adapted for different spatial scales and global regions to calculate changes in ambient air pollution.

- Comprehensive Air Quality Model with Extensions [CAMx; (112)] is similar to CMAQ, but with somewhat reduced flexibility and associated computational cost. CAMx was used in six studies $(26,72,74,78,87,93)$.

- Weather Research and Forecasting model coupled with Chemistry [WRF-Chem; (113)] is similar to CMAQ and CAMx, but also allows for the analysis of air pollution impacts on weather and climate (e.g., the role of PM in cloud formation); WRF-Chem was used by Zhao et al. (78).

Seven reduced-form models were used across eleven studies to calculate ambient air quality effects, as well as health and economic metrics. Reduced-form models are computationally less intensive, allowing for the analysis of multiple emission scenarios, comparison across geographic regions, or the comparison of co-benefits across models. Three studies used multiple reduced-form models and presented health and economic co-benefits comparisons and averages across the models $(83,86,90)$.

- Tracking and Analysis Framework [TAF; (114)] was used by Burtraw et al. (23).
- Air Pollution Emission Experiments and Policy [APEEP/AP2; (115)] was used in three studies $(82,83,90)$.

- CO-Benefits Risk Assessment [COBRA; (116)] was used in two studies $(75,79,83)$.

- Electrical Policy Simulation Tool for Electrical Grid Interventions [EPSTEIN; (117)] was used in two studies $(81,86)$.

- Estimating Air pollution Social Impact Using Regression [EASIUR; (118)] was used in three studies $(73,83,90)$.

- Intervention Model for Air Pollution [InMAP; (119)] was used in Dimanchev et al. (77).

Reported human health benefit metrics include premature mortality, years of potential life lost, and disability-adjusted life years, which are calculated with concentration-response functions developed by epidemiology or toxicology health studies. Economic valuations of health outcomes are estimated with willingness to pay and value of a statistical life methods. EPA's Environmental Benefits Mapping and Analysis Program (BenMAP) (120) is the only model that exclusively calculates health and economic benefits. Eight studies linked full physics air quality model outputs with BenMAP to calculate premature mortality and the associated monetary benefit $(72-74,78,84,85$, $88,94)$. Three studies calculate public health benefits without the use of a model $(60,65,71)$.

\section{RESULTS}

These 26 studies demonstrate the complexity of the air quality cobenefits research nexus. Some shared patterns and conclusions have emerged to further the scientific understanding of air quality co-benefits. Air quality co-benefits of decarbonization are not universal nor guaranteed $(26,74,76)$, but do present large opportunities to decrease $\mathrm{O}_{3}$ and $\mathrm{PM}_{2.5}$ concentrations and reduce human population exposure to these healthdamaging pollutants.

\section{Decreasing Fossil Fuel Use Reduces Emissions and Improves Air Quality}

These studies consistently found that decreasing fossil fuel use resulted in a roughly linear decrease in precursor emissions, and a non-linear improvement in secondary air pollutant concentrations. The removal of fossil fuel emissions is generally proportional to avoided emissions of $\mathrm{NO}_{\mathrm{x}}, \mathrm{SO}_{2}$, or primary $\mathrm{PM}_{2.5}$ (either on a sectoral or total basis). However, the response of ambient air pollution is sub-linear, showing percentage improvements much less than the percentage total reduction in precursor emissions.

Abel et al. (85) reported that a $12 \%$ summertime baseload electricity demand reduction due to energy efficiency could yield a decrease of $13.2 \%$ in $\mathrm{NO}_{\mathrm{x}}$ emissions and a decrease of $12.6 \%$ in $\mathrm{SO}_{2}$ emissions. However, the model calculated ambient near-surface $\mathrm{PM}_{2.5}$ concentrations decreasing by $0.55 \%$ and $\mathrm{O}_{3}$ concentrations decreasing by $0.45 \%$. The sub-linear relationship between emissions reductions and ambient concentrations may be explained by dispersion and mixing of emissions through the 
atmosphere, diluting the impact of near-surface concentration changes, as well as non-linearities associated with chemical processes and removal from the atmosphere through dry and wet deposition. This same pattern was found by Abel et al. (84) where a $17 \%$ solar photovoltaic (PV) scenario in the Eastern U.S. The $17 \%$ reduction in fossil-based grid-electricity reduced $\mathrm{NO}_{\mathrm{x}}$ emissions by $20 \%$ and $\mathrm{SO}_{2}$ emissions by $15 \%$, whereas ambient surface-level $\mathrm{PM}_{2.5}$ decreased by only $4.7 \%$. Plachinski et al. (80) found that a $59 \%$ decrease in $\mathrm{SO}_{2}$ emissions produced a $3-$ $13 \%$ decrease in ambient sulfate PM. Razeghi et al. (91) found that adding wind generation to charge EVs reduced ambient, near-surface $\mathrm{PM}_{2.5}$ and $\mathrm{O}_{3}$, but not to scale with the amount of renewable energy added. This sub-linear relationship between emissions reduction and air quality improvements highlights the complexity of air quality analysis and the value of advanced air quality models for policy assessments.

There is also interest in the impact of energy system changes on peak daily-or even hourly-ambient pollution levels. Air quality regulations for criteria pollutants in the United States are in part based on peak pollution days, through compliance with the National Ambient Air Quality Standards [NAAQS; (92)]. Air quality regulations are based on annual and short-term concentration averages, depending on the pollutant. Ozone is regulated based on maximum daily 8 -h concentration averages; $\mathrm{PM}_{2.5}$, on both a yearly and daily standard (8). To evaluate whether energy system changes improve compliance with these air quality standards, assessments must evaluate whether air quality improvements occur on the "dirtiest" air pollution days.

The evaluation of regulatory outcomes in these studies builds on earlier co-benefit analyses conducted for federal agencies (14, 15). More recently Regulatory Impact Analyses (RIA) for carbon-related federal regulations have also addressed the impact on NAAQS attainment. For example, the Phase 2 GHG Emissions and Fuel Efficiency Standards RIA reported that nine counties modeled to exceed the NAAQS annual $\mathrm{PM}_{2.5}$ standard in the reference case would have decreased annual $\mathrm{PM}_{2.5}$ concentrations by $0.01-0.03 \mu \mathrm{g} / \mathrm{m}^{3}$ with the vehicle standards (92). Potential NAAQS benefits of energy system change were also included in some published studies, typically requiring the use of advanced air quality models like CMAQ.

The solar energy study by Abel et al. (84) found the largest reductions in $\mathrm{PM}_{2.5}$ on the most polluted days, suggesting that increased PV offers a strategy for potential compliance with the NAAQS for $\mathrm{PM}_{2.5}$. The energy efficiency study by Abel et al. (85) calculated a reduction in the number of days violating the $\mathrm{O}_{3}$ NAAQS in counties across the United States. An analysis of California's climate legislation by Zapata et al. (71) found $\mathrm{PM}_{2.5}$ concentrations were reduced by $2-3 \mu \mathrm{g} / \mathrm{m}^{3}$ over most urban areas during weather conditions that often produce air pollution exceeding federal standards (see Appendix I for supplementary information on how weather and climate change impact air quality). In the same study, the San Joaquin Valley had increased $\mathrm{PM}_{2.5}$ concentrations of $0.3 \mu \mathrm{g} / \mathrm{m}^{3}$ due to further use of dairy biogas as renewable energy. Overall, the literature suggests that decarbonization strategies impact on peak pollution days, suggesting energy system change as a potential strategy to support $\mathrm{PM}_{2.5}$ and $\mathrm{O}_{3}$ NAAQS attainment.

Just as Zapata et al. (71) found greater $\mathrm{PM}_{2.5}$ concentration reductions over urban areas, Zhao et al. (78) also reported uneven spatial distribution of air quality improvements from deep decarbonization scenarios in California. The largest $\mathrm{PM}_{2.5}$ reductions occurred in the largest four metropolitan regions, coinciding with some of the most polluted urban areas of the state. In that study, air quality improvements varied across the decarbonization scenarios.

\section{Reductions in $\mathrm{PM}_{2.5}$ Yield Maximum Health Benefits}

Because $\mathrm{PM}_{2.5}$ is the air pollutant most directly linked to premature mortality (121), reducing fine PM results in the highest public health benefits. The U.S. EPA has determined a causal relationship exists between $\mathrm{PM}_{2.5}$ and mortality, for both long- and short-term exposure (122). The U.S. EPA economic analysis guidelines use the central estimate (mean) value of a statistical life (VSL) of \$7.4 million (\$2006) (123). A large population's exposure to even a small reduction in $\mathrm{PM}_{2.5}$ concentrations can decrease mortality and consequently result in substantial monetized co-benefits.

The majority of health benefits reported in the studies were due to the changes in $\mathrm{PM}_{2.5}$ levels, particularly sulfate $\mathrm{PM}_{2.5}$ from coal-fired power plants $(26,72,73,75,82)$. In Driscoll et al. (73), the reduction of $\mathrm{PM}_{2.5}$ avoided about 3,000 premature deaths, ten times the number of premature deaths avoided by ambient $\mathrm{O}_{3}$ reductions. Wiser et al. (82) reported that reducing $\mathrm{SO}_{2}$ emissions, and subsequently particulate sulfate concentrations, accounted for more than $60 \%$ of the monetized co-benefits.

\section{Displaced Coal Generation and Population Exposure Strongly Affect Co-benefit Valuation}

Renewable energy deployment and climate policies have the highest health and economic benefits in highly populated regions near or downwind from coal-powered electricity generation. Per energy units, coal power plants emit more $\mathrm{CO}_{2}$ than other energy sources, including natural gas (124), and have higher emissions of $\mathrm{SO}_{2}, \mathrm{NO}_{\mathrm{x}}$, and $\mathrm{PM}_{2.5}$ (125).

Because coal has historically been cheaper than natural gas, many regions of the United States rely on coal-fired power plants for base-load electricity. However, the energy mixing is changing rapidly as natural gas has become abundant and cheap due to unconventional production (126). In addition, decreasing costs of wind, solar, and storage technologies have also made these alternatives cost-competitive (127). Because coal power plants are retiring each year, the choice of base year for health impact assessments can strongly affect calculated health benefits. In fact, a retrospective evaluation of 2013 U.S. renewable portfolio standards compliance obligations found that reductions in $\mathrm{SO}_{2}$ emissions from coal power plants accounted for $77-83 \%$ of calculated public health benefits (75). 
In model-based studies, both Buonocore et al. (86) and Millstein et al. (83) found the largest health co-benefits from renewable energy and energy efficiency in the Upper Midwest and Mid-Atlantic. These regions have the most coal electricity generation in the United States. Both studies also found the smallest air quality co-benefits in California. California has one of the cleanest electricity generation mixes, with only one instate coal-fired power plant supplying $0.14 \%$ of the state's electric load (128). Large regional differences in air quality benefits from solar and wind renewable energy deployment are attributable to the fuel displaced by renewable energies (83). Buonocore et al. (81) found that avoided $\mathrm{SO}_{2}$ emissions from coal displacement dominated total air quality benefits, due to their role in forming sulfate $\mathrm{PM}_{2.5}$. Abel et al. (84) also found the Ohio River Valley had the largest air quality benefits within their study region of the Eastern United States. When considering the potential for solar to reduce coal emissions, Wiser et al. (82) reported the greatest co-benefits in Texas, Oklahoma, Louisiana, Arkansas, and other parts of the Southeast due to a climate favorable for solar energy deployment.

The health benefits of air quality improvement depend on population exposure. As a result, co-benefits are greatest where large populations experience large air quality improvements $(75,78,84,86)$. These air quality and health outcomes occur at the urban and regional scale, providing local benefits to reduced fossil fuel use, complementing the global benefits of reducing GHG emissions. Furthermore, the air quality and health benefits occur immediately after fossil fuel emissions decrease, in contrast to the decadal to centuries timescales over which climate responds to changes in radiative forcing. In fact, Driscoll et al. (73) found that implementing national carbon standards for power plants yields immediate, local benefits. Buonocore et al. (86) found the highest co-benefits in the Upper Midwest and the lowest in California due both to displaced fossil fuel and population exposure. This localized aspect of air quality improvement has environmental justice implications. Since many disadvantaged communities are disproportionately likely to live next to pollution point sources (i.e., power plants and industry facilities), their exposure to pollution could be reduced to a greater degree (129).

\section{The Monetized Value of Co-benefits Typically Exceed Implementation Costs}

Monetized air quality health co-benefits were found to offset costs of climate policy implementation or renewable energy deployment, as shown in Figure 3. In comparing a national clean energy standard, an economy-wide cap and trade policy, and a clean transportation policy, Thompson et al. (72) calculated that $26-1,050 \%$ of the policy implementation costs would be offset by monetized health benefits. A comparison of regional climate policies found that the benefits of a cap-and-trade system exceed the implementation costs by more than a factor of 8 , and the benefits of a clean energy standard exceed the implementation costs by almost a factor of 2 (74). Dimanchev et al. (77) estimate that co-benefits from subnational renewable portfolio standards outweigh implementation costs by $34 \%$. A retrospective study of renewable portfolio standards reported that the yearly monetized public health co-benefits exceed yearly compliance costs of this climate policy (75). These U.S. focused studies correspond with the conclusions of Nemet et al. (32), which concluded that the economic co-benefit estimates had a similar order of magnitude to the policy abatement costs.

Figure 4 compares monetized air quality benefits of PV and wind vs. deployment costs reported as $\$ / \mathrm{MWh}$ or $\mathrm{c} / \mathrm{kWh}$ $(\$ 0.01 / \mathrm{kWh})$. Millstein et al. (83) calculated the benefits to be equal to or greater than the levelized cost of electricity (LCOE) for wind and utility solar. LCOE describes the cost of electricity per electricity produced ( $\$ / \mathrm{MWh}$ or $\$ / \mathrm{kWh}$ ) and is a commonly used metric to compare different energy generation types. Buonocore et al. (81) also reported that the monetized economic benefits of renewable energies were the same order of magnitude of the U.S. Energy Information Administration's (EIA) LCOE for renewables. The one exception is residential solar PV, which has high deployment costs stemming from the lack of economies of scale. Dimanchev et al. (77)'s calculated benefits per kWh of renewable energy deployed (average of $8 \mathrm{c}$ per $\mathrm{kWh}$ ) also exceed the solar and wind's LCOE of $4 \mathrm{c}$ per $\mathrm{kWh}$. Wiser et al. (82) analyzed increased solar of $14 \%$ by 2030 and $27 \%$ by 2050 , which reduced air pollutant emissions by about $10 \%$. This resulted in co-benefits valued at $1.4 \mathrm{c}$ of co-benefits per $\mathrm{kWh}$ of solar installed. The levelized cost of electricity for wind and solar PV as well as the price of electricity are included as a comparison $(85,130)$. All but two co-benefits exceed the LCOE of renewables, indicating that air quality benefits alone exceed the cost of deployment.

The reported air quality co-benefits research almost universally demonstrates that both renewable energy deployment and climate policies are cost-effective ways to reduce the public health burden of energy, supporting the synergy between climate and air quality policies. Comparisons of different types of carbon policies concluded that more flexible carbon policies are less costly but can yield similar air quality co-benefits. The regional economy-wide cap and trade policy analyzed by Thompson et al. (74) was cheaper than the compared regional clean energy standard while the air quality and human health benefits for both policies were comparable. Thus, the benefits per implementation cost were higher for the cap-and-trade. Similarly, Thompson et al. (72) reported diminishing benefits with increased stringency of national carbon policies. Driscoll et al. (73) also found that stringent but flexible power plant carbon standards yielded the most health benefits, and Dimanchev et al. (77) found that a price on carbon yielded higher human health co-benefits compared to a renewable portfolio standard since the carbon standard applied to the whole economy and as such was more flexible. A study of deep decarbonization policies in California found the more expensive technological pathway (by $\$ 25$ billion) still yielded a larger net benefit (health co-benefits minus GHG abatement costs) by $\$ 59$ billion (78).

\section{Some Energy Strategies Yield a Mix of Benefits and Disbenefits}

Air quality and health disbenefits can occur in some scenarios, depending on the implementation of an energy policy. These 


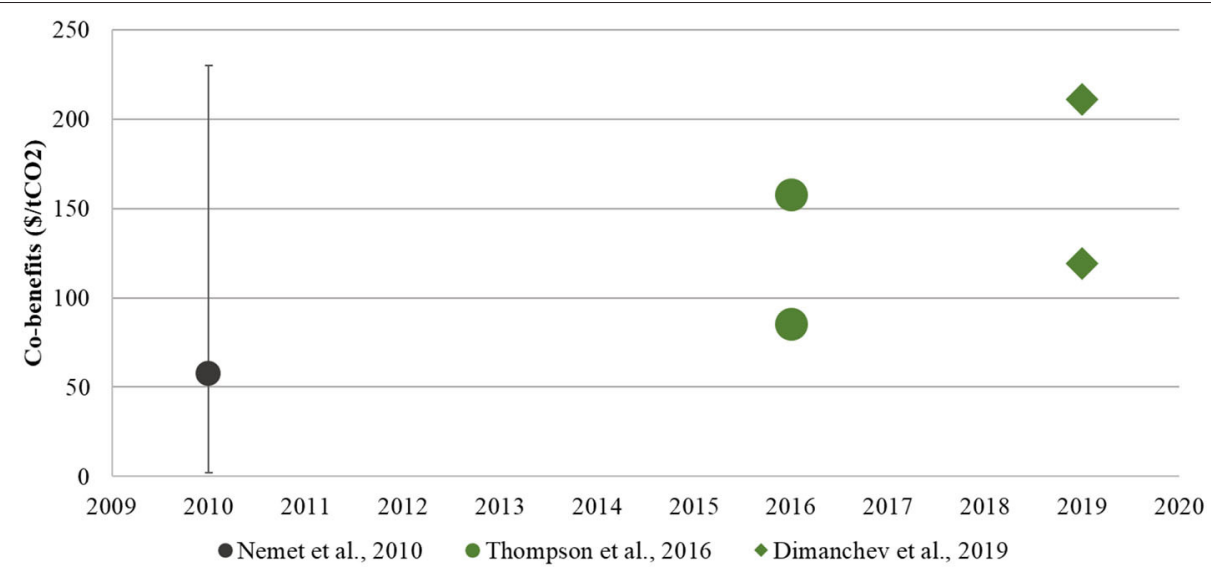

FIGURE 3 | Graph of the three studies that include air quality and public health co-benefits monetized as U.S. dollars per ton of $\mathrm{CO}_{2}(\$ / \mathrm{tCO} 2)$. These are reported from left to right by date of study (2010-2019). Nemet et al. (32)'s range of co-benefits value review is included as a comparison. All values have been adjusted for inflation to 2019 US $\$(36,74,77)$.

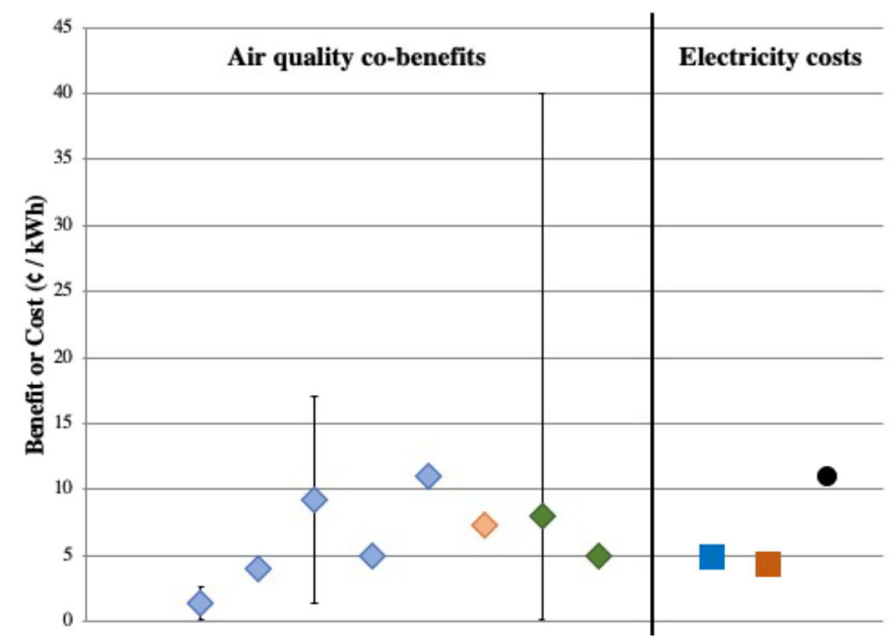

$\diamond$ Co-benefits of solar PV $\diamond$ Co-benefits of wind $\diamond$ Co-benefits of renewable energy - LCOE solar PV -LCOE onshore wind - Cost of Electricity (2018)

FIGURE 4 | Graph of the five studies that include air quality and public health co-benefits monetized as cents per kWh (c/kWh) as well as levelized cost of energy (LCOE) for solar PV and onshore wind and U.S. average electricity costs in July 2018 (77, 81-83, 85).

disbenefits have occurred in models that capture economic feedbacks from changing fuel prices, sectoral shifts in energy demand and/or non-linear chemical processes associated with $\mathrm{O}_{3}$ formation.

As an example of economic factors leading to isolated disbenefits, Thompson et al. (74) found that a Clean Energy Standard in the Northeast resulted in decreased demand for coal in that region, subsequently lowering coal prices. As a result, the demand for coal increased in other regions. Sectoral shifts in energy demand can move emissions, air pollution, and health costs from one area to another, causing localized increases in the region of increased fossil fuel combustion. Electrifying transportation is the most widely studied sectoral shift, as greater EV utilization reduces on-road combustion by conventional vehicles, but may increase power plant combustion to provide electricity to the EVs. This shift typically affects the location of emissions, with lower emissions on roadways and potentially higher emissions at power plants. The shift also affects the timing of emissions, with lower emissions during the day due to reduced on-road emissions during driving. Instead, power plants are operating to charge EVs, especially overnight. Thus, air pollution emissions shift spatially from the tailpipe to nearby power plants and temporally from daytime to nighttime (26, 87). Ebrahimi et al. (76) found that electrifying transportation systems in California resulted in air quality improvements in highly populated areas with poor air quality, but also localized $\mathrm{O}_{3}$ and $\mathrm{PM}_{2.5}$ concentrations next to electricity generating units. The potential disbenefits of vehicle electrification depend on the sources of electricity. Ambient $\mathrm{PM}_{2.5}$ has been found to increase if EVs charging is supplied by coal-power plants (26). However, 
a study in California did not see increased $\mathrm{PM}_{2.5}$ concentrations (91) because the electricity grid serving Los Angeles relies on no coal-fired electricity generation. While EVs can improve local air quality, benefits may be lost if charging is powered by coal power plants. Weis et al. (90) found that switching from conventional vehicles to EVs with the contemporary PJM grid resulted in worse health outcomes; EVs were found to produce health benefits if coal plants were retired and wind capacity increased (90). Another example of sectoral shifts yielding a mix of benefits and disbenefits was found by Bickford et al. (89), where a modal shift of freight movement from truck to rail reduced $\mathrm{NO}_{\mathrm{x}}, \mathrm{PM}_{2.5}$, and $\mathrm{O}_{3}$ concentrations, but found local increases in pollution close to the railroads with higher levels of activity.

Potential disbenefits from emission reductions can also arise from the non-linear chemical processes controlling $\mathrm{O}_{3}$ formation. Chemical production of $\mathrm{O}_{3}$ is limited by the availability of VOCs (Volatile Organic Compounds) relative to $\mathrm{NO}_{\mathrm{x}}$, so areas with high $\mathrm{NO}_{\mathrm{x}}$ and lower VOCs (such as urban centers and power plant plumes) can exhibit a negative relationship between $\mathrm{NO}_{\mathrm{x}}$ and $\mathrm{O}_{3}$. In these conditions, reducing $\mathrm{NO}_{\mathrm{x}}$ actually increases $\mathrm{O}_{3}$ concentrations. Studies reviewed here found an increase in urban $\mathrm{O}_{3}$ in Houston, Denver, Newark, and a regional study of the PJM territory $(26,87,94)$.

Despite this localized disbenefit, multiple studies found $\mathrm{O}_{3}$ concentrations to decrease with replacing conventional vehicles with EVs, especially on peak pollution days. The regional PJM from Thompson et al. (26) found $20 \%$ replacement with plugin hybrid EVs resulted in $\mathrm{O}_{3}$ decreases between 2 and $6 \mathrm{ppb}$ across the region's urban areas during a modeled historic air pollution episode. An analysis of $100 \%$ PHEVs penetration in Denver, Colorado found a 2-3 ppm reduction of $\mathrm{O}_{3}$ on days with the highest $\mathrm{O}_{3}$ concentrations in the base-case (87). In Houston, modeling $35 \% \mathrm{EV}$ penetration resulted in an air pollution episode average $\mathrm{O}_{3}$ concentration decrease of 3-4 ppb (94). Modeling $40 \%$ light-duty electric vehicles penetration in the Los Angeles air basin, Razeghi et al. (91) found widespread $\mathrm{O}_{3}$ decreases across their study region, with localized $\mathrm{O}_{3}$ increases near electricity generation units. Grabow et al. (88) also saw widespread benefits and local $\mathrm{O}_{3}$ disbenefit when replacing short automobile trips $(<8 \mathrm{~km})$ in the Upper Midwest with active transit options, like walking and biking. Concentrations of $\mathrm{PM}_{2.5}$ decreased across the region, including cities (especially during high pollution episodes); $\mathrm{O}_{3}$ decreased in non-urban areas and small cities, but increased in larger cities.

\section{CONCLUSION}

Coupled and reduced-form models reflecting energy system change, atmospheric processes, and health impacts draw from and require multidisciplinary thinking and teams. Studies using a variety of approaches consistently find a high value of air quality and health benefits to clean energy. This research has increased awareness that co-benefits are an important component of energy policy valuation. Across published studies, both reduced-form and advanced models are used, often with qualitatively similar results. This is consistent with the structured reduced-form and full-physics model comparison in Gilmore et al. (131). While reduced-form models provide policymakers a general estimate of co-benefits, they are not typically consistent with the rigorous expectations of compliance with U.S. Clean Air Act planning (such as State Implementation Plans).

Even given the differences in methods and assumptions, overall the air quality conclusions are consistent across research studies. Monetized public health benefits fall within a 50$250 \$ / \mathrm{tCO}_{2}$, aligning with a previously reported range. The central values of air quality co-benefits $(\mathrm{c} / \mathrm{kWh})$ deviate little, with a standard deviation of only $3 \mathrm{c} / \mathrm{kWh}$. These health valuations are dominated by the mortality impacts of $\mathrm{PM}_{2.5}$ exposure. It is unclear if a similar level of agreement would exist for specific health outcomes and/or pollutant exposure beyond $\mathrm{PM}_{2.5}$.

Although air quality and climate change have environmental justice consequences, none of the studies discussed here specifically consider low-income and communities of color. These communities have historically faced the greatest air pollution burdens (129) and are now the most vulnerable to climate change impacts (132). Tools exist to support this type of analysis, including explicit characterization of age, race, and ethnicity in BenMAP, and environmental justice characterization in the reduced-form InMAP model.

Another gap in published studies includes the potential "leakage" of emissions and air quality impacts from regional or statewide climate mitigation policies and strategies. Given the state-to-state transfer of electricity, as well as state-tostate transfer of air pollution in the atmosphere, any analysis over a fixed region will not capture the full impact of energy policies. Only one study quantified this leakage of indirect air quality increases from a northeast clean energy standard and carbon price (74). The leakage impacts of regional and statewide policies would be a valuable issue to explore further, given the interconnected nature of energy systems, transportation infrastructure, and federal air pollution control in the United States.

Decarbonization policies have effects beyond climate mitigation and air quality. Household energy budgets and lifestyle changes (e.g., increased physical activity) are also affected and have interlocking impacts on public health. For example, Grabow et al. (88) found eliminating short vehicle trips ( $\leq 8 \mathrm{~km}$ round trip) and replacing half of those trips with bicycling reduces premature mortality per year 2 -fold: about 600 fewer deaths from improved air quality and almost 700 fewer deaths from increased physical activity. These additional impacts could also be integrated into health co-benefits analyses.

Studies to date showcase the potential for energy system change to benefit air quality and public health. However, it is still unusual for energy changes to be included in statelevel planning under the Clean Air Act. Energy analyses regularly characterize $\mathrm{CO}_{2}$ emission impacts, but rarely $\mathrm{NO}_{\mathrm{x}}$ or $\mathrm{SO}_{2}$. The disconnect between these issues misses the potential for "win-win" solutions for carbon reductions and public health benefits. Moving forward, policy and planning stand to benefit from the wealth of models and methods to 
support integrated analysis of energy, air quality, and health. The beneficial health findings can promote decarbonization strategies, and multi-pollutant solutions for health-damaging air pollution.

\section{DATA AVAILABILITY STATEMENT}

The original contributions presented in the study are included in the article/supplementary material, further inquiries can be directed to the corresponding author/s.

\section{AUTHOR CONTRIBUTIONS}

CG and TH contributed to the design and execution of the literature review, to the analysis of the results, and to the writing of the manuscript.

\section{REFERENCES}

1. West JJ, Cohen A, Dentener F, Brunekreef B, Zhu T, Armstrong B, et al. What we breathe impacts our health: improving understanding of the link between air pollution and health. Environ Sci Technol. (2016) 50:4895-904. doi: 10.1021/acs.est.5b03827

2. Cohen AJ, Brauer M, Burnett R, Anderson HR, Frostad J, Estep K, et al. Estimates and 25-year trends of the global burden of disease attributable to ambient air pollution: an analysis of data from the Global Burden of Diseases Study 2015. Lancet. (2017) 389:1907-18. doi: 10.1016/S0140-6736(17)30505-6

3. Jacobson TA, Kler JS, Hernke MT, Braun RK, Meyer KC, Funk WE. Direct human health risks of increased atmospheric carbon dioxide. Nat Sustain. (2019) 2:697-701. doi: 10.1038/s41893-019-0323-1

4. WHO. Air Quality Guidelines (2005).

5. U.S. Environmental Protection Agency. NAAQS. (2016) Available online at: URL https://www.epa.gov/criteria-air-pollutants/naaqs-table (accessed December 10, 2019).

6. The European Union. Air Quality Standards. EU Air Qual. Dir (2008). Available online at: URL https://www.eea.europa.eu/themes/air/air-qualityconcentrations/air-quality-standards.

7. China State Council. Air Pollution Prevention and Control Action Plan (2013).

8. U.S. Environmental Protection Agency. Nonattainment Areas for Criteria Pollutants. (2020) Available online at: URL https://www.epa.gov/green-book

9. Jacob DJ, Winner DA. Effect of climate change on air quality. Atmos Environ. (2009) 43:51-63. doi: 10.1016/j.atmosenv.2008.09.051

10. Weaver CP, Liang XZ, Zhu J, Adams PJ, Amar P, Avise J, Caughey M, et al. A preliminary synthesis of modeled climate change impacts on U.S. regional ozone concentrations. Am Meteorol Soc. (2009) 1843-63. doi: $10.1175 / 2009 B A M S 2568.1$

11. Ayres R, Walter J. The greenhouse effect: damages, costs and abatement. Environ Resource Econ. (1991) 1:237-70. doi: 10.1007/BF00367920

12. Viscusi WK, Magat WA, Carlin A, Dreyfus MK. Environmentally responsible energy pricing. Energy J. (1994) 15:43-66. doi: 10.5547/ISSN0195-6574-EJ-Vol15-No2-2

13. Wang Z, Smith KR. Secondary benefits of greenhouse gas control: health impacts in China. Environ Sci Technol. (1999) 33:3056-61. doi: 10.1021/es981360d

14. Dowlatabadi H, Tschang F, and Siegel S. Estimating the Ancillary Benefits of Selected Carbon Dioxide Mitigation Strategies: Electricity Sector. Climate Change Division, US Environmental Protection Agency (1993).

15. Holmes R, Keinath D, Sussman F. Ancillary Benefits of Mitigating Climate Change: Selected Actions from the Climate Change Action Plan. Climate Change Division, US Environmental Protection Agency (1993).

\section{ACKNOWLEDGMENTS}

Support for this research was provided by the Joyce Foundation Environment Program, and the Office of the Vice Chancellor for Research and Graduate Education at the University of Wisconsin-Madison with funding from the Wisconsin Alumni Research Foundation. We appreciate comments and input provided by Dr. David Abel, Dr. Paul Meier, Sunjoo Hwang, and Magdelaine Dickinson, as well as helpful comments from reviewers.

\section{SUPPLEMENTARY MATERIAL}

The Supplementary Material for this article can be found online at: https://www.frontiersin.org/articles/10.3389/fpubh. 2020.563358/full\#supplementary-material

16. Aunan K, Fang J, Vennemo H, Oye K, Seip HM. Co-benefits of climate policy-lessons learned from a study in Shanxi, China. Energy Policy. (2004) 32:567-81. doi: 10.1016/S0301-4215(03)00156-3

17. Bollen J, van der Zwaan B, Brink C, Eerens H. Local air pollution and global climate change: a combined cost-benefit analysis. Resour Energy Econ. (2009) 31:161-81. doi: 10.1016/j.reseneeco.2009. 03.001

18. Tollefsen P, Rypdal K, Torvanger A, Rive N. Air pollution policies in Europe: efficiency gains from integrating climate effects with damage costs to health and crops. Environ Sci Policy. (2009) 12:870-81. doi: 10.1016/j.envsci.2009.08.006

19. United Nations. Convention on Long-Range Transboundary Air Pollution 81/462/EEC (1979).

20. Alcamo J, Shaw R, Hordijk L. The RAINS Model of Acidification. Science and Strategies in Europe (1990).

21. Syri S, Karvosenoja N, Lehtilä A, Laurila T, Lindfors V, Tuovinen JP. Modeling the impacts of the Finnish Climate Strategy on air pollution. Atmos Environ. (2002) 36:3059-69. doi: 10.1016/S1352-2310(02)00263-7

22. van Vuuren DP, Cofala J, Eerens HE, Oostenrijk R, Heyes C, Klimont Z, et al. Exploring the ancillary benefits of the Kyoto Protocol for air pollution in Europe. Energy Policy. (2006) 34:444-60. doi: 10.1016/j.enpol.2004.06.012

23. Burtraw D, Krupnick A, Palmer K, Paul A, Toman M, Bloyd C. Ancillary benefits of reduced air pollution in the US from moderate greenhouse gas mitigation policies in the electricity sector. J Environ Econ Manage. (2003) 45:650-73. doi: 10.1016/S0095-0696(02)00022-0

24. Zhang D, Aunan K, Martin Seip H, Larssen S, Liu J, Zhang D. The assessment of health damage caused by air pollution and its implication for policy making in Taiyuan, Shanxi, China. Energy Policy. (2010) 38:491-502. doi: 10.1016/j.enpol.2009.09.039

25. Fann N, Fulcher CM, Hubbell BJ. The influence of location, source, and emission type in estimates of the human health benefits of reducing a ton of air pollution. Air Qual Atmos Heal. (2009) 2:169-76. doi: 10.1007/s11869-009-0044-0

26. Thompson T, Webber M, Allen DT. Air quality impacts of using overnight electricity generation to charge plug-in hybrid electric vehicles for daytime use. Environ Res Lett. (2009) 4:014002. doi: 10.1088/1748-9326/4/1/014002

27. Zhao B, Xu J, Hao J. Impact of energy structure adjustment on air quality: a case study in Beijing, China. Front Environ Sci Eng China. (2011) 5:378-90. doi: 10.1007/s11783-011-0357-8

28. Bell ML, Davis DL, Cifuentes LA, Krupnick AJ, Morgenstern RD, Thurston GD. Ancillary human health benefits of improved air quality resulting from climate change mitigation. Environ Heal A Glob Access Sci Source. (2008) 7:1-18. doi: 10.1186/1476-069X-7-41

29. Haines A, McMichael AJ, Smith KR, Roberts I, Woodcock J, Markandya A, et al. Public health benefits of strategies to reduce greenhouse-gas emissions: 
overview and implications for policy makers. Lancet. (2009) 374:2104-14. doi: 10.1016/S0140-6736(09)61759-1

30. Ravishankara AR, Dawson JP, Winner DA. New directions: adapting air quality management to climate change: a must for planning. Atmos Environ. (2012) 50:387-9. doi: 10.1016/j.atmosenv.2011.12.048

31. Swart R, Amann M, Raes F, Tuinstra W. A good climate for clean air: Linkages between climate change and air pollution: an editorial essay. Clim Change. (2004) 66;263-9. doi: 10.1023/B:CLIM.0000044677.41293.39

32. Nemet GF, Holloway T, Meier P. Implications of incorporating air-quality cobenefits into climate change policymaking. Environ Res Lett. (2010) 5:014007. doi: 10.1088/1748-9326/5/1/014007

33. Jacobson MZ. Effects of biomass burning on climate, accounting for heat and moisture fluxes, black and brown carbon, and cloud absorption effects. $J$ Geophys Res Atmos. (2014) 119:8980-9002. doi: 10.1002/2014JD021861

34. Jacobson MZ. Strong radiative heating due to the mixing state of black carbon in atmospheric aerosols. Nature. (2001) 409:695-7. doi: $10.1038 / 35055518$

35. Trail MA, Tsimpidi AP, Liu P, Tsigaridis K, Hu Y, Rudokas JR, et al. Impacts of potential CO2-reduction policies on air quality in the United States. Environ Sci Technol. (2015) 49:5133-41. doi: 10.1021/acs.est.5b00473

36. West JJ, Smith SJ, Silva RA, Naik V, Zhang Y, Adelman Z, et al. Co-benefits of global greenhouse gas mitigation for future air quality and human health. Nat Clim Chang. (2013) 3:885-9. doi: 10.1038/nclimate2009

37. Fann N, Baker KR, Fulcher CM. Characterizing the PM2.5-related health benefits of emission reductions for 17 industrial, area and mobile emission sectors across the U.S. Environ Int. (2012) 49:141-51. doi: 10.1016/j.envint.2012.08.017

38. Ou Y, Shi W, Smith SJ, Ledna CM, West JJ, Nolte CG, et al. Estimating environmental co-benefits of U.S. low-carbon pathways using an integrated assessment model with state-level resolution. Appl Energy. (2018) 216:48293. doi: 10.1016/j.apenergy.2018.02.122

39. U.S. Environmental Protection Agency (2015). Regulatory Impact Analysis for the Final Clean Power Plan.

40. Boyd R, Krutilla K, Viscusi WK. Energy taxation as a policy instrument to reduce $\mathrm{CO}_{2}$ emissions: a net benefit analsyis. J Environ Econ Manage. (1995) 29:1-24. doi: 10.1006/jeem.1995.1028

41. Kan H, Chen B, Chen C, Fu Q, Chen M. An evaluation of public health impact of ambient air pollution under various energy scenarios in Shanghai, China. Atmos Environ. (2004) 38:95-102. doi: 10.1016/j.atmosenv.2003.09.038

42. Schmid D, Korkmaz P, Blesl M, Fahl U, Friedrich R. Analyzing transformation pathways to a sustainable European energy systemInternalization of health damage costs caused by air pollution. Energy Strateg Rev. (2019) 26:100417.doi: 10.1016/j.esr.2019.100417

43. Scovronick N, Budolfson M, Dennig F, Errickson F, Fleurbaey M, Peng W, et al. The impact of human health co-benefits on evaluations of global climate policy. Nat Commun. (2019) 10:499. doi: 10.1038/s41467-019-09499-x

44. Cifuentes L, Borja-aburto VH, Gouveia N, Thurston G, Environmental S, Perspectives $\mathrm{H}$, et al. Assessing the health benefits of urban air pollution reductions associated with climate change mitigation (2000-2020): Santiago, São Paulo, México City, and New York City. Environ Health Perspect. (2017) 109:419-25. doi: 10.2307/3434790

45. Kim SE, Xie Y, Dai H, Fujimori S, Hijioka Y, Honda Y, et al. Air quality cobenefits from climate mitigation for human health in South Korea. Environ Int. (2020) 136:105507. doi: 10.1016/j.envint.2020.105507

46. Markandya A, Armstrong BG, Hales S, Chiabai A, Criqui P, Mima $S$, et al. Public health benefits of strategies to reduce greenhouse-gas emissions: low-carbon electricity generation. Lancet. (2009) 374:2006-15. doi: 10.1016/S0140-6736(09)61715-3

47. Shindell D, Faluvegi G, Seltzer K, Shindell C. Quantified, localized health benefits of accelerated carbon dioxide emissions reductions. Nat Clim Chang. (2018) 8:291-5. doi: 10.1038/s41558-018-0108-y

48. Wang T, Jiang Z, Zhao B, Gu Y, Liou K, Kalandiyur N, et al. Health co-benefits of achieving sustainable net-zero greenhouse gas emissions in California. Nat Sustain. (2020) 3:597-605. doi: 10.1038/s41893-020-0520-y

49. Jacobson MZ, Colella WG, Golden DM. Atmospheric science: cleaning the air and improving health with hydrogen fuel-cell vehicles. Science. (2005) 308:1901-5. doi: 10.1126/science.1109157
50. Markandya A, Sampedro J, Smith SJ, Van Dingenen R, Pizarro-Irizar C, Arto I, et al. Health co-benefits from air pollution and mitigation costs of the paris agreement: a modelling study. Lancet Planet Heal. (2018) 2:e126-33. doi: 10.1016/S2542-5196(18)30029-9

51. Rauner S, Hilaire J, Klein D, Strefler J, Luderer G. Air quality co-benefits of ratcheting up the NDCs. Clim Change. (2020). doi: 10.1007/s10584-020-02699-1

52. Sampedro J, Smith SJ, Arto I, González-Eguino M, Markandya A, Mulvaney $\mathrm{KM}$, et al. Health co-benefits and mitigation costs as per the paris agreement under different technological pathways for energy supply. Environ Int. (2020) 136:105513. doi: 10.1016/j.envint.2020.105513

53. Shindell DT, Lee Y, Faluvegi G. Climate and health impacts of US emissions reductions consistent with $2^{\circ}$ c. Nat Clim Chang. (2016) 6:503-7. doi: $10.1038 /$ nclimate 2935

54. Vandyck T, Keramidas K, Tchung-Ming S, Weitzel M, Van Dingenen R. Quantifying air quality co-benefits of climate policy across sectors and regions. Clim Change. (2020). doi: 10.1007/s10584-020-02685-7

55. Rauner S, Bauer N, Dirnaichner A, Dingenen R, Van Mutel C, Luderer G. Coal-exit health and environmental damage reductions outweigh economic impacts. Nat Clim Chang. (2020) 10:308-12. doi: 10.1038/s41558-020-0728-x

56. Abel DW, Holloway T, Harkey M, Meier P, Ahl D, Limaye VS, et al. Air-quality-related health impacts from climate change and from adaptation of cooling demand for buildings in the eastern United States: an interdisciplinary modeling study. PLoS Med. (2018) 15:127. doi: 10.1371/journal.pmed.1002599

57. Chen Y, Hobbs BF, Hugh Ellis J, Crowley C, Joutz F. Impacts of climate change on power sector NOx emissions: a long-run analysis of the US mid-atlantic region. Energy Policy. (2015) 84:11-21. doi: 10.1016/j.enpol.2015.04.013

58. Weis A, Jaramillo P, Michalek J. Consequential life cycle air emissions externalities for plug-in electric vehicles in the PJM interconnection. Environ Res Lett. (2016) 11:024009. doi: 10.1088/1748-9326/11/2/024009

59. Caton R, Constable S. Clearing the Air: A Preliminary Analysis of Air Quality Co-Benefits from Reduced Greenhouse Gas Emissions in Canada (2000).

60. Chen K, Guo H, Hu J, Kota S, Deng W, Ying Q, et al. Projected air quality and health benefits from future policy interventions in India. Resour Conserv Recycl. (2019) 142:232-44. doi: 10.1016/j.resconrec.2018.12.008

61. Ferrero E, Alessandrini S, Balanzino A. Impact of the electric vehicles on the air pollution from a highway. Appl Energy. (2016) 169:450-9. doi: 10.1016/j.apenergy.2016.01.098

62. Li N, Chen JP, Tsai IC, Chi SY, Lin YC, et al. Potential impacts of electric vehicles on air quality in Taiwan. Sci. Total Environ. (2016) 566-7:919-28. doi: 10.1016/j.scitotenv.2016.05.105

63. Liang X, Zhang S, Wu Y, Xing J, He X, Zhang KM, et al. Air quality and health benefits from fleet electrification in China. Nat Sustain. (2019) 2:962-71. doi: 10.1038/s41893-019-0398-8

64. Lin WY, Hsiao MC, Wu PC, Fu JS, Lai LW, Lai HC. Analysis of air quality and health co-benefits regarding electric vehicle promotion coupled with power plant emissions. J Clean Prod. (2020) 247:119152. doi: 10.1016/j.jclepro.2019.119152

65. McCollum DL, Krey V, Riahi K, Kolp P, Grubler A, Makowski M, et al. Climate policies can help resolve energy security and air pollution challenges. Clim Change. (2013) 119:479-94. doi: 10.1007/s10584-013-0710-y

66. Peng W, Yang J, Lu X, Mauzerall DL. Potential co-benefits of electrification for air quality, health, and CO2 mitigation in 2030 China. Appl Energy. (2018) 218:511-9. doi: 10.1016/j.apenergy.2018.02.048

67. Soret A, Guevara M, Baldasano JM. The potential impacts of electric vehicles on air quality in the urban areas of Barcelona and Madrid (Spain). Atmos Environ. (2014) 99:51-63. doi: 10.1016/j.atmosenv.2014. 09.048

68. Van De Ven DJ, Sampedro J, Johnson FX, Bailis R, Forouli A, Nikas A, et al. Integrated policy assessment and optimisation over multiple sustainable development goals in Eastern Africa. Environ Res Lett. (2019) 15:039602. doi: 10.1088/1748-9326/ab49ad

69. Vandyck T, Keramidas K, Kitous A, Spadaro JV, Van Dingenen R, Holland M, et al. Air quality co-benefits for human health and agriculture counterbalance costs to meet Paris Agreement pledges. Nat Commun. (2018) 9:4939. doi: 10.1038/s41467-018-06885-9 
70. Wolkinger B, Haas W, Bachner G, Weisz U, Steininger K, Hutter HP, et al. Evaluating health co-benefits of climate change mitigation in urban mobility. Int J Environ Res Public Health. (2018) 15:1-27. doi: 10.3390/ijerph15050880

71. Zapata C, Muller N, Kleeman MJ. PM2.5 co-benefits of climate change legislation part 1: California's AB 32. Clim Change. (2013) 117:377-97. doi: 10.1007/s10584-012-0545-y

72. Thompson TM, Rausch S, Saari RK, Selin NE. A systems approach to evaluating the air quality co-benefits of US carbon policies. Nat Clim Chang. (2014) 4:917-23. doi: 10.1038/nclimate2342

73. Driscoll CT, Buonocore JJ, Levy JI, Lambert KF, Burtraw D, Reid SB, et al. US power plant carbon standards and clean air and health co-benefits. Nat Clim Chang. (2015) 5:535-40. doi: 10.1038/nclimate2598

74. Thompson TM, Rausch S, Saari RK, Selin NE. Air quality co-benefits of subnational carbon policies. J Air Waste Manag Assoc. (2016) 66:988-1002. doi: 10.1080/10962247.2016.1192071

75. Barbose G, Wiser R, Heeter J, Mai T, Bird L, Bolinger M, et al. A retrospective analysis of benefits and impacts of U.S. renewable portfolio standards. Energy Policy. (2016) 96:645-60. doi: 10.1016/j.enpol.2016.06.035

76. Ebrahimi S, Mac Kinnon M, Brouwer J. California end-use electrification impacts on carbon neutrality and clean air. Appl Energy. (2018) 213:435-49. doi: 10.1016/j.apenergy.2018.01.050

77. Dimanchev EG, Paltsev S, Yuan M, Rothenberg D, Tessum CW, Marshall JD, et al. Health co-benefits of sub-national renewable energy policy in the US. Environ Res Lett. (2019) 14:085012. doi: 10.1088/1748-9326/ab31d9

78. Zhao B, Wang T, Jiang Z, Gu Y, Liou K-N, Kalandiyur N, et al. Air quality and health co-benefits of different deep decarbonization pathways in California. Environ Sci Technol. (2019) 53:7163-71. doi: 10.1021/acs.est.9b02385

79. McCubbin D, Sovacool BK. Quantifying the health and environmental benefits of wind power to natural gas. Energy Policy. (2013) 53:429-41. doi: 10.1016/j.enpol.2012.11.004

80. Plachinski SD, Holloway T, Meier PJ, Nemet GF, Rrushaj A, Oberman JT, et al. Quantifying the emissions and air quality co-benefits of lower-carbon electricity production. Atmos Environ. (2014) 94:180-91. doi: 10.1016/j.atmosenv.2014.03.028

81. Buonocore JJ, Luckow P, Norris G, Spengler JD, Biewald B, Fisher J, et al. Health and climate benefits of different energy-efficiency and renewable energy choices. Nat Clim Chang. (2016) 6:100-6. doi: 10.1038/nclimate2771

82. Wiser MD, Mai T, Macknick J, Carpenter A, Cohen S, Cole W, et al. The environmental and public health benefits of achieving high penetrations of solar energy in the United States. Energy. (2016) 113:472-86. doi: 10.1016/j.energy.2016.07.068

83. Millstein D, Wiser R, Bolinger M, Barbose G. The climate and air-quality benefits of wind and solar power in the United States. Nat Energy. (2017) 2:1-10. doi: 10.1038/nenergy.2017.134

84. Abel DW, Holloway T, Harkey M, Rrushaj A, Brinkman G, Duran P, et al. Potential air quality benefits from increased solar photovoltaic electricity generation in the Eastern United States. Atmos Environ. (2018) 175:65-74. doi: 10.1016/j.atmosenv.2017.11.049

85. Abel DW, Holloway T, Martínez-Santos J, Harkey M, Tao M, Kubes $\mathrm{C}$, et al. Air quality-related health benefits of energy efficiency in the United States. Am Chem Soc. (2019) 53:3987-98. doi: 10.1021/acs.est.8b 06417

86. Buonocore JJ, Hughes EJ, Michanowicz DR, Heo J, Allen JG, Williams A. Climate and health benefits of increasing renewable energy deployment in the United States. Environ Res Lett. (2019) 14:114010. doi: 10.1088/1748-9326/ab49bc

87. Brinkman GL, Denholm P, Hannigan MP, Milford JB. Effects of plug-in hybrid electric vehicles on ozone concentrations in Colorado. Environ Sci Technol. (2010) 44:6256-62. doi: 10.1021/es101076c

88. Grabow ML, Spak SN, Holloway T, Brian SS, Mednick AC, Patz JA. Air quality and exercise-related health benefits from reduced car travel in the midwestern United States. Environ Health Perspect. (2012) 120:68-76. doi: 10.1289/ehp.1103440

89. Bickford E, Holloway T, Karambelas A, Johnston M, Adams T, Janssen M, et al. Emissions and air quality impacts of truck-to-rail freight modal shifts in the Midwestern United States. Environ Sci Technol. (2014) 48:446-54. doi: $10.1021 /$ es4016102
90. Weis A, Michalek JJ, Jaramillo P, Lueken R. Emissions and cost implications of controlled electric vehicle charging in the U.S. PJM interconnection. Environ Sci Technol. (2015) 49:5813-9. doi: 10.1021/es505822f

91. Razeghi G, Carreras-Sospedra M, Brown T, Brouwer J, Dabdub D, Samuelsen S. Episodic air quality impacts of plug-in electric vehicles. Atmos Environ. (2016) 137:90-100. doi: 10.1016/j.atmosenv.2016.04.031

92. U.S. Environmental Protection Agency. Greenhouse Gas Emissions and Fuel Efficiency Standards for Medium- and Heavy-Duty Engines and Vehicles Phase 2 Regulatory Impact Analysis (2016).

93. Nopmongcol U, Grant J, Knipping E, Alexander M, Schurhoff R, Young D, et al. Air quality impacts of electrifying vehicles and equipment across the United States. Environ Sci Technol. (2017) 51:2830-7. doi: 10.1021/acs.est.6b04868

94. Pan S, Roy A, Choi Y, Eslami E, Thomas S, Jiang X, et al. Potential impacts of electric vehicles on air quality and health endpoints in the Greater Houston Area in 2040. Atmos Environ. (2019) 207:38-51. doi: 10.1016/j.atmosenv.2019.03.022

95. Requia WJ, Mohamed M, Higgins CD, Arain A, Ferguson M. How clean are electric vehicles? Evidence-based review of the effects of electric mobility on air pollutants, greenhouse gas emissions and human health. Atmos Environ. (2018) 185:64-77. doi: 10.1016/j.atmosenv.2018.04.040

96. Boyd E. Overview of Power Sector Modeling in: Office of Energy Policy and Systems Analysis. U.S Department of Energy (2016).

97. Ringkjøb HK, Haugan PM, Solbrekke IM. A review of modelling tools for energy and electricity systems with large shares of variable renewables. Renew Sustain Energy Rev. (2018) 96:440-59. doi: 10.1016/j.rser.2018.08.002

98. Rausch S, Reilly JM, Metcalf GE, Paltsev S. Distributional implications of alternative U.S. greenhouse gas control measures. B E J Econ Anal Policy. (2010) 10: 1-44. doi: 10.2202/1935-1682.2537

99. Paul A, Burtraw D, Palmer K. Haiku Documentation: Electricity Market Model Version 2.0. Washington, DC: Resources for the Future (2009). Available online at: https://media.rff.org/documents/RFF-Rpt-Haiku.v2.0. pdf

100. Meier Engineering Research LLC. MyPower(TM) Electricity-Sector Model (2011).

101. Lenox C, Dodder R, Gage C, Loughlin D, Kaplan O, Yelverton W. EPA U.S. Nine-region MARKAL Database Documentation. Cincinnati, OH (2013).

102. National Renewable Energy Laboratory. Regional Energy Deployment System (ReEDS) (2019).

103. ICF Resources L.L.C. Integrated Planning Model (IPM $\left.{ }^{\circledR}\right)$ (2019).

104. Feng X, Tang L, Wang Z, Yang J, Wong W, Chao H, et al. A new breed of software tool for integrated electrical power system and market analysis - GridView. Power Energy Soc. Summer Meet. (2002) IEEE 2:737-43. doi: 10.1109/PESS.2002.1043404y

105. U.S. Environmental Protection Agency. AVoided Emissions and geneRation Tool (AVERT) (2019).

106. Porter CD, Brown A, DeFlorio J, McKenzie EWT. Effects of travel reduction and efficient driving on transportation: energy use and greenhouse gas emissions. Prep Natl Renew Energy Lab. (Golden, CO). Washington, DC: Cambridge Syst. Inc. (Cambridge, MA), U.S. Dep. Energy (2013). p. 98. doi: 10.2172/1219932

107. Zhang L, Hong J, Nasri A, Shen Q. How built environment affects travel behavior: a comparative analysis of the connections between land use and vehicle miles traveled in US cities. J Transp Land Use. (2012) 5:40-52. doi: 10.5198/jtlu.v5i3.266

108. U.S. Environmental Protection Agency. MOtor Vehicle Emission Simulator (MOVES) (2018).

109. Argonne National Laboratory. Greenhouse Gases, Regulated Emissions, and Energy Use in Transportation (GREET) Model (2013).

110. California Air Resources Board. Mobile Source Emissions Inventory Modeling Tools. (2017) Available online at: https://ww2.arb.ca.gov/ourwork/programs/mobile-source-emissions-inventory/msei-modeling-tools

111. U.S. Environmental Protection Agency. Community Multiscale Air Quality Modeling System (CMAQ) (2019).

112. Ramboll Environ. Comprehensive Air Quality Model with Extensions. (CAMx) (2018)

113. National Center for Atmospheric Research. WRF-Chem. (2018) 
114. Bloyd C, Camp J, Conzelmann G, Formento J, Molburg J, Shannon J. Tracking and analysis framework (TAF) model documentation and user's guide, ANL/DIS/ TM-36. (1996). doi: 10.2172/491416. Available online at: https://www.osti.gov/biblio/491416-55ykdu/webviewable/

115. Muller NZ. Boosting GDP growth by accounting for the environment. Science. (2014) 345:873-4. doi: 10.1126/science.1253506

116. U.S. Environmental Protection Agency. User's Manual for the Co-Benefits Risk Assessment (COBRA) Screening Model. (2014) Available online at: https://www.epa.gov/statelocalenergy/co-benefits-risk-assessmentcobra-health-impacts-screening-and-mapping-tool

117. Buonocore JJ, Hughes E, Heo J, Williams A, Michanowicz DR, Allen JG. Development and Demonstration of the Environmental Policy Simulation Tool for Electrical Grid Interventions (Epstein), Version 2.0, In: International Society for Environmental Epidemiology (ISEE). (2018) doi: 10.1289/isesisee.2018.O01.02.52

118. Heo J, Adams P, Gao HO. Reduced-form modeling of public health impacts of inorganic PM2.5 and precursor emissions. Atmos Environ. (2016) 137:809. doi: 10.1016/j.atmosenv.2016.04.026

119. Tessum CW, Hill JD, Marshall JD. InMAP: a model for air pollution interventions. PLoS ONE. (2017) 12:176131. doi: 10.1371/journal.pone. 0176131

120. Abt Associates Inc. BenMAP, Environmental Benefits Mapping and Analysis Program. User's Manual, Version 4.0 (2012).

121. Brunekreef B, Holgate ST. Air pollution and health. Lancet. (2002) 360:123342. doi: 10.1016/S0140-6736(02)11274-8

122. U.S. Environmental Protection Agency. Integrated Science Assessment for Particulate Matter. Research Park Triangle, NC (2019).

123. U.S. Environmental Protection Agency. Guidelines for Preparing Economic Analyses (2010).

124. Wigley TML. Coal to gas: the influence of methane leakage. Clim Change. (2011) 108:601-8. doi: 10.1007/s10584-011-0217-3
125. U.S. Energy Information Administration. Electricity Emissions by Plant and by Region (2018).

126. Wang Q, Chen X, Jha AN, Rogers H. Natural gas from shale formation - The evolution, evidences and challenges of shale gas revolution in United States. Renew Sustain Energy Rev. (2014) 30:1-28. doi: 10.1016/j.rser.2013.08.065

127. IRENA. Electricity Storage and Renewables: Costs and Markets to 2030, Electricity-Storage-and-Renewables-Costs-and-Markets. Abu Dhabi (2017).

128. California Energy Commission. California's Declining Reliance on Coal. Sacramento (2018).

129. Miranda ML, Edwards SE, Keating MH, Paul CJ. Making the environmental justice grade: The relative burden of air pollution exposure in the United States. Int J Environ Res Public Health. (2011) 8:1755-71. doi: 10.3390/ijerph8061755

130. Lazard. Levelized Cost of Energy Analysis. (2019) Available online at: https:// www.lazard.com/perspective/LCOE2019

131. Gilmore EA, Heo J, Muller NZ, Tessum CW, Hill JD, Marshall JD, et al. An inter-comparison of the social costs of air quality from reduced-complexity models. Environ Res Lett. (2019) 14:074016. doi: 10.1088/1748-9326/ablab5

132. US Global Change Research Program. The Impacts of Climate Change on Human Health in the United States: A Scientific Assessment (2016).

Conflict of Interest: The authors declare that the research was conducted in the absence of any commercial or financial relationships that could be construed as a potential conflict of interest.

Copyright (C) 2020 Gallagher and Holloway. This is an open-access article distributed under the terms of the Creative Commons Attribution License (CC BY). The use, distribution or reproduction in other forums is permitted, provided the original author(s) and the copyright owner(s) are credited and that the original publication in this journal is cited, in accordance with accepted academic practice. No use, distribution or reproduction is permitted which does not comply with these terms. 